\title{
Building Teacher Identity in a New Partnership Project, - Multiple Perspectives
}

\author{
Kirsti Vindal Halvorsen \\ Faculty of engineering and science, University of Agder \\ PO Box 422, NO-4604 Kristiansand, Norway \\ Tel: 47-92-082-415Ｅ-mail: kirsti.v.halvorsen@uia.no
}

Received: Dec. 2, 2013 Accepted: December 10, 2013 Published: February 1, 2014

doi:10.5296/jse.v4i1.4655 URL: http://dx.doi.org/10.5296/jse.v4i1.4655

\begin{abstract}
This paper explores the process of identity building among novice student teachers enrolled in a newly established partnership project embedded in a four-year Norwegian teacher education program. The empirical evidence in the study is drawn from a case study where interviews were the main method of gathering data. The analysis of narratives from the interviews is premised on multiple perspectives. The findings are presented as a reconstructed story with a plot in which the novice student teachers are the chief protagonists. The study illuminates both catalysts and inhibitors of student teachers' identity building in the caring contexts of teaching practice and threatening contexts of theory, and in more play-like contexts bridging theory and practice. It indicates that the theoretical part of the teacher education program may give rise to a theory shock among novice student teachers that appears to have been in the shadow of the well-documented practice shock.
\end{abstract}

Keywords: Identities, Contexts, Student teachers, Partnership, Teacher education 


\section{Introduction}

The focus of the current study is the dynamic relation between student teachers' professional identity building and their learning environment that is situated in a partnership project within a Norwegian teacher education program. More precisely, the central issue in the paper is an investigation of the processes involved in becoming a student teacher in a new partnership project. Research shows that a core issue is at stake when student teachers find the practical part of the program more meaningful for their future profession than the theoretical part (Korthagen, 2001). Moreover, Flores and Day (2006) point to the impact of the student teachers' backgrounds, their experiences as elementary and high school students, and the quality of their motivation for becoming a teacher. From their backgrounds, the student teachers have often formed an image of the kind of teacher they want to become based on their own school experiences, constituting "apprenticeships of observation” (Flores \& Day 2006; quoting Lortie, 1975) and on collectively narrated stories about teachers (Sfard \& Prusak, 2005). This can be called student teachers' desired identity as future teachers. However, when facing the reality of a practice placement in schools as pre-service teachers, they may realize that there are risks involved in being the kind of teachers they have dreamt of. Several narratives mention the tensions, frustrations and struggles involved in bridging the gap between what they "want-to-be" and what they perceive other people signal they “ought-to-be” (Beauchamp \& Thomas, 2009; Bullough \& Draper, 2004; Sfard \& Prusak, 2005). Consequently, the gap between "want-to-be" and "ought-to-be" is seen as the vulnerable part, or the Achilles heel, of their professional identity building.

At the same time, the well-known gap between theory and practice is described as the Achilles heel of teacher education programs (Zeichner, 2010; quoting Darling-Hammond, 2009). In order to "cure" the Achilles heel, or to counteract criticism, mainly of the gap between theory and practice, partnerships have been developed between universities and schools. These partnerships are built on the assumption that universities and schools have very distinct contributions to make to student teachers' professional development. Since neither can be reduced to the other, these different perspectives need to be brought into dialogue with each other (Furlong et al., 2008). Indeed, as a result of dialogue based on mutual respect between university-based teacher educators and cooperating teachers in the schools, successful partnership stories have emerged about supporting student teachers' professional development in a dynamic way, as part of an innovative teacher education program and school development (Baumfield \& Butterworth, 2007; Darling-Hammond 2010). However, rival narratives exist that raise issues related to demanding tasks (Magolda, 2001) and time-consuming procedures (Lemke \& Sabelli, 2008). Building a partnership is especially vulnerable when deeply felt differences in values and beliefs between university-based teacher educators and cooperating teachers emerge, and the student teachers involuntarily experience themselves in the middle of the tension between them (Bullough \& Draper, 2004). Based on the above discussion, the research question of the current paper is:

How is the identity building process of student teachers formed in the contexts of a new partnership project? The answer to this question is framed within multiple perspectives. 


\section{Theoretical perspective}

The study examines the identity building of novice student teachers in their learning environment during teacher education at a university, as well as during practice placement in schools. It focuses on the processes of becoming a teacher in the transition from school student to student teacher that embraces the emotional and social dimensions of learning. Identity building is explored in terms of the following thematic structure:

o Personas: social identity, positioning and agency

o Sense-making: the usefulness of sociocultural contexts

o Self-in-contexts: individual identity and sense-making

\subsection{Personas: social identity, positioning and agency}

The image of the caring and kind teacher has been found to be a preferred social identity among Norwegian teachers (Søreide, 2006), and culturally elaborated social identities of this kind can be described as personas (Holland \& Leander, 2004). Personas are articulated in narratives and operate as a repertoire of legitimate social identities (Czarniawska, 2004). Moreover, a persona presents an image for school students and for novice student teachers of what being a teacher may be like (Holland \& Leander, 2004). Selective identification with personas influences the construction of student teachers' desired identity as future teachers. Acting in accordance with one's own desired identity represents the achievement of a "want-to-be" position in teaching contexts and is described as an achievement of agency (Holland \& Leander, 2004). However, powerful persons, such as cooperating teachers and university-based teacher educators, are likely to present other social positions and the student teachers are then faced with a dilemma. Should they be true to their own desired image or act in accordance with the teachers' suggestions? Whatever choice they make may cause emotional stress that unfolds in teaching and learning contexts (Holland \& Leander, 2004). Emotions and power relations are viewed as mediated aspects that color the novice student teachers' assessment of the usefulness of different contexts in their education (Thompson, 2007).

\subsection{Sense-making: the usefulness of socio-cultural contexts}

The current study is informed by the view that people, in this instance student teachers, make sense of contexts in terms of how useful they are in pursuit of their own values, interests and goals (Thompson, 2007). Their sense-making of contexts embraces three cultural aspects, which Bateson (1972) has characterized as being linked to emotions, structure and pragmatics (85). With regard to the affective aspect, it is said that: "Emotion is about pleasure and pain, approach and avoidance” (Nesse \& Ellsworth, 2009, p.130). Hence positive emotions, such as desire and hope, are likely to motivate student teachers to take advantage of the opportunities that arise in various contexts, whereas negative emotions, such as fear, motivate them to try to avoid misfortunes (Nesse \& Ellsworth, 2009). At the same time, the structural aspect is concerned with social forces, power relations and the potential risk of experiencing tension between "want-to-be” and “ought-to-be” positions (Holland \& Leander, 2004). The 
pragmatic aspect is connected to what is going on in these contexts. The student teachers' sense-making of all these cultural aspects stands in a dynamic, interdependent relationship to their identity building (Thompson, 2007).

\subsection{Self-in-context: individual identity and sense-making}

Subjective experiences of being oneself in a diversity of contexts throughout life give rise to a self-produced interpretative framework that reflects the processes of identity building (Thompson, 2007). In here and now situations, identity is colored by past experiences interlaced with values, memories and narratives. Identity is moreover viewed as the basis for all manner of choices and decision-making that affect human beings (Holstein \& Gubrium, 2000). It operates like a lens, which helps to make sense of the usefulness of a context and to cope with the challenges it presents (Thompson, 2007). Identity is seen as synonymous with a person's subjective interpretative framework, while sense-making is the act of interpreting socio-cultural contexts. Narratives are viewed as a central device for making sense of changes in social life (Czarniawska, 2004). Thus, making sense of teaching contexts with the eyes of a school student, although operating in the position of teacher-to-be, can be a way to understand documented stories recounting practice shock experiences (Korthagen, 2001). However, when their understandings and expectations about what it means to be a teacher are not met, student teachers start to search for explanations (Weick, Sutcliffe \& Obstfeld, 2005). Their stories often provide plausible answers as to why something unpredictable happened (Czarniawska, 2004), and they are valued for their usefulness in promoting the beneficial outcome (Weick et al., 2005). As a consequence of this, student teachers may gradually reject making sense of teaching contexts from the perspective of their past experiences as school students. Instead they may value a framework where adjustments help to make sense of teaching contexts with the eyes of a teacher-to-be. Changing the ways of making sense of questions about why something happens opens the doors to identity building as it changes the ways of understanding the contexts (Bateson, 1972). Stories relating such changes are viewed as articulated accounts of identity building, and they are, at the same time, nourished by collectively told stories (Sfard \& Prusak, 2005).

Selective identification with teacher personas enhances the construction of a desired identity of a "want to be" position. Power relations may, however, push student teachers into "ought-to-be" positions in contexts that are characterized by the three cultural aspects, namely emotions, structure and pragmatics. These subjective experiences influence the identity of student teachers and are articulated in their narratives.

\section{The study}

This qualitative case study is part of a larger project exploring student teachers' development at different stages of a developing partnership. The current study deals with the initial stage, which is marked by a dual set of beginnings concerning building up a new identity as student teachers who are situated in a newly established partnership project between university-based teacher educators and cooperating teachers. The analytical unit is a triad composed of three student teachers, two university-based teacher educators, and two cooperating teachers in schools. In the following the different kind of teachers are referred to as university teachers 
and cooperating teachers. Case methodology is used to explore the complex relations and processes of change in social life (Stake, 2005).

\subsection{Setting}

At the time when the study took place there where three main kinds of teacher education programs in Norway related to kindergarten, elementary and junior high schools, and high schools. On a local level, the universities that offer teacher education programs had to commit themselves to the curriculum prescribed by the national authority. The current case is situated in a four-year general teacher education program for elementary and junior high school teachers. Previously, the university-led program had followed an established tradition whereby responsibilities were divided between the cooperating teachers and the university teachers, mainly as regards practical and theoretical matters. Communication was limited to two meetings per year, one before each practice placement period. It was at such a meeting that the practice field was informed about the forthcoming partnership model. The new model aimed at creating a richer dialogue between teacher educators and cooperating teachers, by establishing a new structure for the program although there was still a lack of clarity about how it could be implemented. The previous three-week practice placement was replaced with one-day practice units over a period of five weeks. The intention was to create a dynamic relationship between the theoretical and the practical part of the program, as student teachers would alternate between participating on one day of teaching practice and attending courses at the university the rest of the week. The new structure was implemented on a small scale with 25 student teachers during the first semester. New ideas emerged during the development process, and these were continuously tested out in the learning environment of the student teachers, both at the university and in the schools. The aim of the partnership project was to support student teachers' professional development.

\subsection{Data collection}

The main research instrument in the current study was qualitative research interviews (Kvale, 1977), which were used to elicit a variety of narratives (Czarniawska, 2004). The principal case participants were: three student teachers, two university teachers, and two cooperating teachers. The interviews took place one and a half years after the new partnership model was established. A semi-structured guided interview technique (Kvale, 1997) was used and adapted according to the case actors' respective positions as student teacher, university teacher, or cooperating teacher. The interview started with questions about the participants' background and then focused on the storyline of the project, subjective experiences of inspiration, frustration, and challenges. The interviews were carried out by the author and lasted for approximately one hour. They were transcribed and sent to the actors for eventual validation or adjustment.

\subsection{Analysis}

The spiral analysis (Cresswell, 2007) is in the following sections described in a linear way. The initial condensation of the content of the interviews focused on the background of the student teachers and their development related to the storyline of the partnership project. The 
categorization of the content emerged by using theoretical prefigured categories in terms of personas (Holland \& Leander, 2004) and contexts (Bateson, 1972). The categories were considered broad enough to capture the specificity of the data. The categorization was validated by informant triangulation (Kvale, 1997) related to collectively narrated elements that emerged across the interviews. A narrative interpretation in the form of a plot structure (Czarniawska, 2004) was used to link together the identified and labeled categories, and to form a holistic case story. A schematic overview of the identified categories and the plot is presented in table 1.

Table 1. A schematic overview of the identified categories and the plotTable 1.

\begin{tabular}{|l|l|l|}
\hline Personas & Contexts & Plot \\
\hline 1. Model teachers & Caring contexts & Equilibrium \\
\hline 2. Guinea pigs & Threatening contexts & Disequilibrium \\
\hline 3. Playmates & Play-like contexts & New equilibrium \\
\hline
\end{tabular}

The identification of the specific personas as model teachers, guinea pigs, and playmates was founded on collectively retold narratives occurring in the interviews. The personas were then linked to three specific contexts, which are labeled according to emotional, cultural and pragmatic aspects (Bateson, 1972). The protagonists in the plot are the student teachers. Their background as students in schools is viewed as a state of equilibrium. This state represents the beginning of the plot. The middle of the plot is described as a state of disequilibrium. It is characterized as a double set of new beginnings. It is, on the one hand, the transition from being a school student to becoming a student teacher but, at the same time, it is embedded in the change in the teacher education program due to the partnership project. The end of the constructed plot is described as a new equilibrium enacted in play-like contexts. In the following section, the plot of the case story is further explored. The excerpts from the interviews are used selectively to secure the anonymity of the case participants.

\section{Findings and discussion}

The findings of the study are presented as a case story. It starts with the desired identity of novice student teachers, which is built on their own experiences as school students. From there, the story goes on to present the student teachers' identity building processes situated in the newly established partnership project. Thirdly, it ends with suggesting promising outcomes that combine the dynamics of identity and partnership building.

\subsection{Model teacher and desired identity}

The stories the student teachers (STs) recounted about ideal teachers (personas) form the basis of the construction of their desired identity as future teachers:

ST3: I want to respect my students, enjoy spending time with them, but also be strict 
and enthusiastic about the subject I am going to teach - just like my best school teachers.

The study supports earlier research pointing to the influence of student teacher' background as students in schools in the process of becoming a teacher. However, the finding nuances the picture by showing how the desired identities of the student teachers are generalized into three model teacher dimensions. The relational dimension (A) is illustrated by the desire to "respect my pupils and enjoy spending time with them". "Be strict" is an illustration of the structural dimension (B). The subject-based dimension (C) is illustrated by the valued goal of being "enthusiastic about the subject I am going to teach". These model teacher dimensions may give a general impression of what lies behind student teachers' identification with the ideal teacher they encountered as school students; it is also described as their "want-to-be" position as a future teacher (Holland \& Leander, 2004). Moreover, the model teachers are seen as enacting the admired values in caring contexts involving good teacher-pupil relations. In the literature, the impact of qualitatively good teacher-pupil relations is described as a success criterion for teachers (Beijard, Verloop \& Vermunt, 2000), the core of the teaching profession (Bullough, Young \& Draper, 2004), and the heart of teaching (Kelchtermans, 2005). More specifically, it is described as the preferred teacher identity in a Norwegian context, "the caring and kind teacher" (Søreide, 2006, p. 536). But, for these student teachers, the model teachers have a multifaceted identity that also incorporates the structural dimension (B), and the subject-based dimension (C). The structural dimension (B) is represented by the trust the student teachers place in the model teachers' ability to structure predictability and to be strict. Being together with model teachers in school was a state of equilibrium, "since you could always trust those teachers, and you knew what to expect” (ST1). This structural dimension is congruent with a success criterion held by secondary school teachers as the model teachers are able to create structure, to plan, to execute and evaluate teaching and learning processes (Beijard et al., 2000). The subject-based dimension (C) is about how the student teachers valued the model teachers because of their knowledge and engagement in the subject they teach. Being expert in a subject is also considered to be a success criterion by teachers in secondary schools (Beijard et al., 2000). In addition, the generalized nature of the student teachers' descriptions of their model teacher embraces the aspect of how they initially make sense of the unfolding contexts in the partnership project in order to pursue their own values and desired identity (Thompson, 2007). However, the way they make sense of the contexts may change on account of further identity building in the course of their education (Bateson, 1972).

\subsection{Building identity}

The school students' initiation into becoming teachers is embedded in the early phase of the partnership project. The combined developmental processes represent a central turning point or disequilibrium in the reconstructed case story. The collectively narrated stories relate how student teachers feel like guinea pigs in the new project due to the continual need to implement new ideas largely proposed by the university teachers. Hence they experience the contexts as threatening, as a result of changes and uncertainties (Bateson, 1972). These findings are presented by using the lens of the model teacher dimensions. They build on the 
view that student teachers make sense of the various contexts in the partnership project in pursuit of own values and goals (Thompson, 2007).

\section{A. The quality of relationships}

At the time when the student teachers (STs) were themselves school students, they admired their model teachers because of their ability to establish good relationships with students. The study shows that in the new contexts of the program, the possibility to encounter such model teachers arose mainly among the cooperating teachers as can be seen in the following extract:

ST1: They are good at seeing our problems, discussing with us, giving advice and supporting us in here and now situations. They understand us because they have been in our shoes before.

The finding confirms earlier research showing that student teachers often report that they want caring cooperating teachers who act as mentors while they are coping with the new challenges of learning to teach (Andersen, 2007). Moreover, the study points to the contrast of the qualities of the relationships between the student teachers and their different teachers. The study suggests that quality of the complementary relationship between cooperating teachers and student teachers is described as one of "caring-dependency" (Bateson, 1972, p.109). On the other hand, the quality of the relationship with the university teachers was more like "dominance-submission" (Bateson, 1972, p.109) because the student teachers felt that their desired identity as future teachers was at stake:

ST2: We got some heavy tasks with too great demands from university teachers, which we had to do during the practice period. We were only thinking about the tasks and nearly forgot the cooperating teacher and the students in the school.

The narrative sense-making of student teachers reveals conflicting emotions that express the quality of their relations with the cooperating teachers and university teachers, embedded in the caring contexts of practice and threatening contexts of theory. These contrasts are seen as a potential inhibitor of student teachers' professional identity building. Perceiving practice as a caring context reinforced the desired identity from their own schooldays, while perceiving theory as a threatening context caused emotions such as fear and demotivation. The disclosed inhibitor of their professional identity building is viewed as a "context issue", based on sociocultural relationships that emerge in the beginning of a new partnership project. The well-documented theory-practice gap is described as a "content issue". The content issue is at stake when student teachers find the content of practice more meaningful for their future profession than the content of theory. By combining the content problem with the context problem, a case scenario emerged suggesting that the process may harm the student teachers' professional identity building if they perceive practice as meaningful, caring contexts and theory as meaningless, threatening contexts.

\section{B. The quality of structure}

The student teachers, while themselves school students, valued the ability of their model teachers to create order and predictability. But the sudden change created by implementing 
the university-led partnership project proved to be a catalyst of uncertainty that was expressed in the collectively narrated stories about feeling like guinea pigs. The guinea pig metaphor may represent a narrative resource in identity building by acting as a persona that offers the student teachers the position of social victim (Holland \& Leander, 2004).

University teacher: Many of the student teachers felt like guinea pigs in the project.

ST1: We felt a little like guinea pigs in the project. Many of the students complained, they wanted to be more closely followed up by the university teachers and to get more information. But I decided to handle it myself, since I am now a student teacher.

The study shows how student teachers' narratives reveal acceptance or rejection of the identification with guinea pigs. Accepting a victim position might have been a successful strategy as school students in caring contexts, but it is a risky strategy in the process of becoming teachers. Being a teacher involves not just taking responsibility for oneself, but also being responsible for students. Hence a paradox was revealed since being a caring university teacher involves pushing reluctant student teachers into taking responsibility themselves. At the same time, the student teachers who did not identify with the guinea pig persona were able to self-regulate so that they took responsibility for their own development. Their self-selected identity building indicates that they no longer make sense of the learning context with the eyes of school students, but with the eyes of teachers-to-be. The deconstruction of naivety in exchange for the reconstruction of responsibility appears to be a necessary initiation process in preparing for the future. However, being a responsible, full-time novice student teacher is a high stake position that may give rise to a reality shock (Flores \& Day, 2006).

C. The quality of competence and engagement in their subject

The student teachers valued model schoolteachers because of their solid competence and engagement in the subject they taught; these were attributes that were also valued in the university teachers:

ST 2: I liked the lectures on this subject, because the university teacher was an expert and really engaged in the subject matter, just like my ideal teachers from school.

The study suggests that complementary relationship in which student teachers acknowledge the expertise of others is described as "spectatorship-exhibitionism" (Bateson, 1972, p.109). However, it was a demanding kind of spectatorship, perceived as a threatening context, or more specifically, as one that led to a "theory shock" because of the unfamiliar, highly theoretical level:

ST3: It was very confusing with all those theories in pedagogy. It was a heavy process that I had to go through, and I thought I would not learn anything at all about them. But the pieces gradually fell into place after I had worked systematically with them... You have to structure yourself in quite a different way as a student teacher, differently from being a school student... It was exciting to be my own boss.

The narrative is seen as an illustration of identity building; it reflects the changing ways of 
viewing the new threatening context with the eyes of a student teacher instead of as a school student. In a similar way, it led to a deeper involvement, the achievement of agency by being one's own boss. But this empowerment was also catalyzed by the "theory shock" and the necessity of deconstructing naivety in order to construct responsibility and develop a sustainable student teacher identity. At the same time, the impact of the "theory shock" seems to be left in the shadow of the well-documented reports of practice shock (Korthagen, 2001; Bullough, Young \& Draper, 2004; Edwards \& Mutton, 2007), which exists despite the perception that teaching is a caring activity.

\subsection{Model teachers: building identities of optimism and mission}

The end of the constructed plot in this study is based on collectively narrated stories about acting like "playmates". The stories illustrate the unique possibilities that may arise through performing in play-like contexts (Bateson, 1972). The stories reflect a state of equilibrium where cheerful engagement is a catalyst in building identity and relationships that give grounds for optimism about the future. These findings are presented using the lens of the model teacher dimension.

\section{A. The quality of relationships}

The collectively narrated stories of playmates were initiated by one of the cooperating teachers presented a new idea to some of the university teachers: the idea of creating a historical school play where all the student teachers and the students would act as if they were living 100 years ago. This was warmly welcomed by some of the university teachers.

A complementary relationship with the quality of a creative, trusting symbiosis developed between cooperating teachers and university teachers, a characteristic of a successful partnership. An example of this is:

University teacher: We have very good discussions with the cooperating teachers based on equality and respect...we knew that everybody was important if we were to succeed.

The finding supports Zeicher (2010) who argues for the necessity of democracy and inclusive collaboration in the processes of building partnership. Moreover, the university teachers and the cooperating teachers attuned themselves to the optimism and commitment of implementing the historical school play. The common values and idealism that were disclosed can be seen as an expression of their preferred professional identities:

Cooperating teacher: I really believe in creating enthusiastic moments of teaching that give the pupils the opportunity to fully understand the theme.

University teacher: We wanted to give the student teachers a unique experience. We do not get academic credit for this project, but we think it is fun and meaningful.

The study shows how the values and visions of the different kind of teachers represented a high degree of congruence across the well-known theory and practice gap. But the excerpts also illustrate the "paradox of play" (Bateson, 1972, p. 191). However enjoyable the 
equilibrium of the play-like context was, it nonetheless revealed a potential threat when confronted with consequences in real life. It seemed to be the university teachers who drew the shortest straw as they risked putting their own academic reputation at stake by committing themselves to participation in the time-consuming historical play project. The potential price to be paid can be described as the schism of "doing good and feeling bad", which represents a documented threatening context in academia (Acker \& Feuerverger, 1996). Doing good seems to be more of a moral imperative in a school culture with kind and caring teachers. However, the university teachers appear to consider it to be a price worth paying since in exchange they nurture their own optimism and act out valued aspects of their preferred identities.

B. The ability to create structure and predictability

The study indicates the impacts of how the student teachers make sense of the historical scenario in contrasting ways, either as a peculiar context of reality or as a context of play (Bateson, 1972). Making sense of the scenario literarily as a context of reality confirmed that they had already achieved their desired identity as a future teacher:

ST1: Order was more valued in the classroom in the old days than it is now. I think it is time to put this on the agenda again, just as my ideal teacher in the school did.

In contrast, making sense of the scenario as a play-like context represents a special kind of meta-perspective without the restraints created by a context of reality (Bateson, 1972). The meta-perspective opens up a landscape of future possibilities, creating new kinds of structure beyond the concrete scenario, an example of this is:

ST 3: It was fun all the time...everything is possible (in the future) if you just find the right persons to cooperate with.

The imagination and creativity discovered in the play-like context seemed to nourish an optimistic attitude towards the challenging reality of teaching. It reflected the attitude of "homo ludens" or the playful human being, and acted as a catalyst for building an identity filled with optimism for the future. It was not just a fantasy picture in a dream plot (Czarniawska, 2004); it was enacted in the real world because of the ability of these new model teachers to cooperate across traditional barriers and thereby create a new kind of structure.

C. Teachers' competence and engagement in their subject

The student teachers were now at the stage of their program where they had to decide on their major subject. For one of the student teachers the issue was no longer about being as knowledgeable as the ideal teacher, but about choosing the right subject as an instrument for realizing her growing sense of mission as a future teacher:

ST 2: I am wondering about what I can be good at, where I can make a difference, and who may need me, because there are many children that have a tough time. I am concerned about immigrant children; that is why I think that the Norwegian language is a very, very important subject. I did not think like this before. 
"Making a difference in students' lives" represents a mission that teachers themselves often say is what keeps them going in the job (Kelchtermans, 2005, p. 999). But idealism and mission may share the paradox of play when confronted with the context of the reality of teaching, since the classroom situations include moments of contingency learning, for example that "teaching is to be vulnerable" (Kelchtermans, 2005, p. 999). This paradox points at the fragility of student teachers' identity building in connection with their future idealism if they overlook the need to build a sustainable resilient security net for coping with contexts of reality. This is something also university teachers and cooperating teachers need to bear in mind.

\section{Summing up}

The case study has explored the process of identity building undergone by novice student teachers in a triad within a new partnership project, viewed from multiple perspectives. The findings are presented as a reconstructed story with a plot in which the novice student teachers are the chief protagonists. The beginning of the plot presented student teachers' desired identity as future teachers, which was influenced by the model teachers they encountered in the caring contexts of schools. The study suggests how a comprehensive depiction of their model teachers has three dimensions: relational, structural and subject-based. The tension that unfolded in the middle of the plot was illustrated by stories where student teachers recounted that they felt like guinea pigs in the partnership project. That gave rise to the interpretation of the identity building of student teachers as an initiation process. However, the student teachers in the current study did not identify themselves with the position of social victims, which being guinea pigs might entail. Instead, the outcome of the process was a deconstruction of naivety in exchange for a reconstruction of responsibility. Moreover, the study indicates that caring contexts in schools may reinforce student teachers' desired identity, which they had acquired as school students. Threatening contexts at a university may either inhibit or act as catalysts of their professional identity building. The end of the plot developed into a play-like situation, where university teachers and cooperating teachers joined hands across the theory-practice gap to create a trusting symbiosis. The play-like sequence imbued the student teachers' identity building with hope and a sense of mission as regards the future. An overview is given in the model below and answers the research question: "How is student teachers' identity building formed in the contexts of a new partnership project?” in the form of a plot. 


\section{Caring contexts}

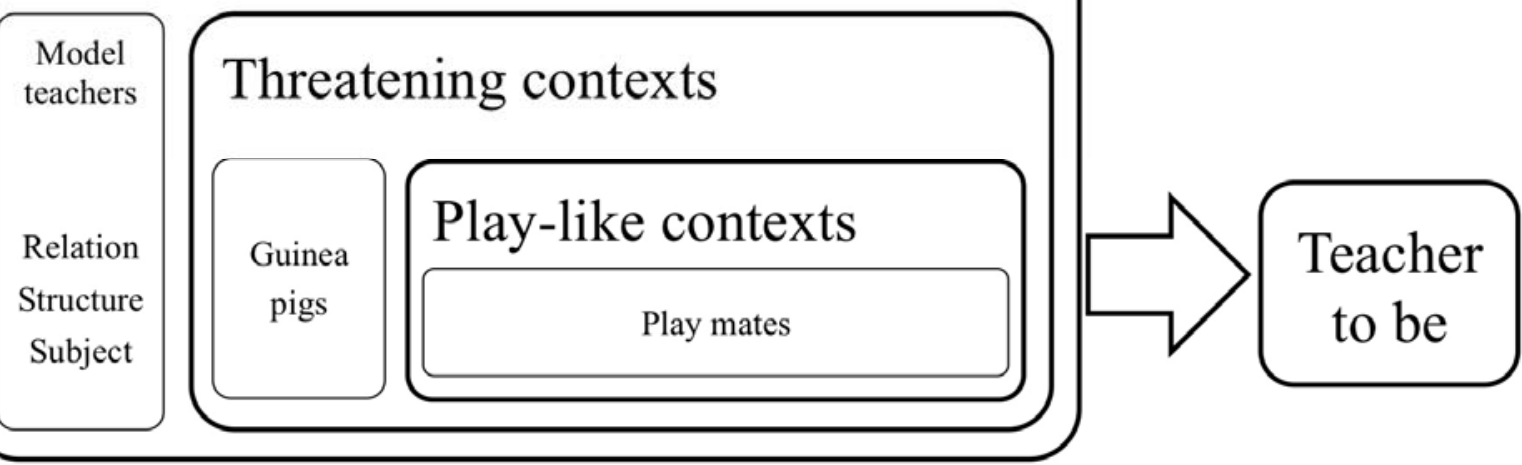

Figure 1. A model of contexts and personas that influence student teachers' identity building in the contexts of a new partnership project

The model combines the impacts of the specific contexts and personas in collectively told stories arising in the process of becoming a student teacher in the contexts of a newly established partnership project. It supports earlier research pointing out that identity building is a context-specific process (Beijard mfl. 2004; Flores \& Day, 2006), involving nuances where the impact of specific contexts is enacted in the triad composed of student teacher, cooperating teachers and university teachers. The model is an illustration of identity building that is founded on the transition from school student to student teacher embedded in a partnership project colored by uncertainties. The threatening contexts in the culture of the university may give rise to a theory shock that seems to have been given little attention in the literature compared with the well-documented studies of practice shock (Korthagen, 2001) and the reality shock of novice student teachers (Flores \& Day, 2006). Moreover, the processes involved in becoming student teachers seem to have been left in the shadow of the documented impact of the transition from student teacher to teacher (Flores \& Day, 2008), and the equally documented formation of teacher identity (Beijard mfl. 2004; Beauchamp \& Thomas, 2009). However, a small study like this can only cast a gleam of light over the identity building of student teachers in a triad situated in a partnership project. It does not give new insight into the processes of building a partnership, rather showing that implementing the idea of partnership easily promotes uncertainty, especially among novice student teachers. Further investigations need to be carried out into the impact of the three different kinds of contexts and also into narratives as resources in building student teachers' identity within more developed partnerships.

\section{References}

Anderson, D. (2007). The role of cooperating teachers' power in student teaching. Education, 128, 307-323. 
Acker, S., \& Feuerverger, G. (1996). Doing good and feeling bad: The work of women university teachers. Cambridge Journal of Education, 26, 401-422. http://dx.doi.org/10.1080/0305764960260309

Bateson, G. (1972). Steps to an Ecology of Mind. New York: Ballantine Books.

Baumfield, V., \& Butterworth, M. (2007). Creating and translating knowledge about teaching and learning in collaborative school-university research partnerships: An analysis of what is exchanged across the partnerships, by whom and how. Teachers and Teaching, 13, 411-427. http://dx.doi.org/10.1080/13540600701391960

Beauchamp, C., \& Thomas, L. (2009). Understanding teacher identity: An overview of issues in the literature and implications for teacher education. Cambridge Journal of Education, 39, 175-189. http://dx.doi.org/10.1080/03057640902902252.

Beijard, D., Meijer, P. C., \& Verloop, N. (2004). Reconsidering research on teachers' professional identity. Teaching and Teacher Education, 20, 107-128. http://dx.doi.org/10.1016/j.tate.2003.07.001

Beijard, D., Verloop, N., \& Vermunt, J. (2000). Teachers' perceptions of professional identity: An exploratory study from a personal knowledge perspective. Teacher and Teacher Education, 16, 749-764. http://dx.doi.org/10.1016/S0742-051x(00)00023-8

Bullough, Jr. R.V., \& Draper, R. J. (2004). Making Sense of a failed triad: mentors, university supervisors and positioning theory. Journal of Teacher Education, 5, 07-420. http://dx.doi.org/10.1177/0022487104269804

Bullough, Jr. R.V., Young, J., \& Draper, R. J. (2004). One-year teaching internships and the dimensions of beginning teacher development. Teachers and Teaching: Theory and Practice, 10, 367-394. http://dx.doi.org/10.1080/1354060042000224124

Cresswell, J. W. (2007). Qualitative Inquiry and Research Design: Choosing among five approaches. Thousand Oaks: Sage Publications Ltd.

Czarniawaska, B. (2004/2009). Narratives in Social Science Research. London: Sage Publications Ltd.

Darling-Hammond, L. (2010). Teacher education and the American future. Journal of Teacher Education, 61, 35-47. http://dx.doi.org/10.1177/0022487109348024

Edwards, A., \& Mutton, T. (2007). Looking forward: Rethinking professional learning through partnership arrangements in Initial Teacher Education. Oxford Review of Education, 33, 503-519. http://dx.doi.org/10.1080/03054980701450928.

Flores, M.A., \& Day, C. (2006). Contexts which shape and reshape new teachers' identities: A multi-perspective study. Teacher and Teacher Education, 22, 219-232.

http://dx.doi.org/10.1016/j.tate.2005.09.002

Furlong, J., McNamara, O., Campbell, A., Howson, J., \& Lewis, S. (2008). Partnership, policy and politics: Initial teacher education in England under New Labour. Teachers and 
Teaching, 14, 307-318. http://dx.doi.org/10.1080/13540600802037728

Holland, D., \& Leander, K. (2004). Ethnographic studies of positions and subjectivity: An introduction. Ethos, 32, 127-139. http://dx.doi.org/ 10.1525/eth.2004.32.2.127

Holstein, J. A., \& Gubrium, J. F. (2000). The Self We Live by. Narrative identity in a postmodern world. New York: Oxford University Press.

Kelchtermans, G. (2005). Teachers' emotions in educational reforms: Self-understanding, vulnerable commitment and micropolitical literacy. Teaching and Teacher Education, 21, 995-1006. http://dx.doi.org/10.1016/j.tate.2005.06.009

Korthagen, F. A. J. (2001). Linking Practice and Theory: The pedagogy of realistic teacher education. Mahwah, N.J.: Lawrence Erlbaum Associates, Inc.

Kvale, S. (1997). Interview: en introduktion til det kvalitative forskningsinterview. København: Hans Reitzels.

Lemke, J. L., \& Sabelli, N. H. (2008). Complex systems and educational change: Towards a new research agenda. Educational Philosophy and Theory, 40, 118-129. http://dx.doi.org/10.1111/j.1469-5812.2007.00401.x

Magolda, P. (2001). Border crossings: Collaboration struggles in education. Journal of Educational Research, 94, 346-358. http://dx.doi.org/ 10.1080/00220670109598772

Nesse, R. M., \& Ellsworth, P. C. (2009). Evolution, emotions and emotional disorders. American Psychologist, 64, 129-139. http://dx.doi.org/10.1037/a0013503

Sfard, A., \& Prusak, A. (2005). Telling identities: In search of an analytical tool for investigating learning as culturally shaped activity. Educational Researcher, 34, 14-22. http://dx.doi.org/10.3102/0013189X034004014

Stake, R. E. (2005). Qualitative case studies. In N. K. Denzin \& Y. S. Lincoln (eds.) The Sage Handbook of Qualitative Research (pp. 443-466). Thousand Oaks: Sage Publications.

Søreide, G. E. (2006). Narrative construction of teacher identity: Positioning and negotiation. Teachers and Teaching: Theory and Practice, 12, 527-547. http://dx.doi.org/10.1080/13540600600832247

Thompson, E. (2007). Mind in Life: Biology, phenomenology and science of mind. Cambridge: Belknap Harvard.

Weick, K. E., Sutcliffe, K. M., \& Obstfeld, D. (2005). Organizing and the process of sense-making. Organization Science, 16, 409-421.

Zeichner, K. (2010). Rethinking the connections between campus courses and fieldexperiences in college- and university-based teacher education. Journal of Teacher Education, 61, 89-99. http://dx.doi.org/10.1177/0022487109347671 